(3) The associated adjuncts to arterial reconstruction are discussed with reference to the acute injury and the chronic obliterative lesion.

I should like to express my thanks to $\mathrm{Mr}$. Norman C. Tanner, F.R.C.S., and Mr. Andrew M. Desmond, F.R.C.S., for their kind interest and help in the preparation of this paper, and to Mrs. J. Mace and Miss Mason for the drawings.

\section{BIBLIOGRAPHY}

BINGHAM, D. L. C (1952), Lancet, ii, 4

BLAKEMORE, A. H., LORD, J. W., Jun., and STEFKO, P. L. (1942), Surgery, 12, 488-508.

CARREL, ALEXIS (1907), Bull. fohns Hopkins Hosp., 18, 18-28.

CARREL, ALEXIS (r910), Ann. Surg., 52, 462.

DONOVAN, T. J. (1949), Ibid., 130, 1024-1043.

Dos SANTOS, J. C. (1947), Mem. Acad. Chir. Paris., 73, 409.

EASTCOTT, H. N. G. (1953), Hunterian Lecture, Royal Coll. Surg. Eng.

EASTCOTT, H. N. G., and HUFNAGEL, C. A. (1952), Lancet, i, 53 I.

FONTAINE, R., and DOS SANTOS, J. C. (1952), Proc. Soc. Europ. \& Chir. Card.-Vasc., 1, 232-338.

GROSS, R. E., BILL, A. H., Jun., and PEIRCE, E. C. (1949), S.G.O., 88, 689 .
HERRMANN, L G. (1947), Am. F. Surg., 74, 560.

HUFNAGEL, C. A., and EASTCOTT, H. N. G. (1950), Surg Forum, Amer. Coll. Surg., 269.

JOHNSON, J., KIRBY, C. K., GREIFENSTEIN, F. E., and CASTILLO, A. (1949), Surgery, 26, 945-956.

KUNLIN, J. (1951), Rev. Clin. Paris, 70, 206.

LE VEEN, H. H. (1949), Arch. Surg., 58, 504-510.

LEXER, E. (1907), Arch. f. Klin. Chir., 83, 458-477.

LINTON, R. R. (1949), New York State F. Med., 49, 2039-2048.

LORD, J. W., Jun. (1950), S. Clin. North America, 30, 377-386.

LOWENBERG, R. I., and SHUMACKER, H. B., Jun. (1949) Arch. Surg., 59, 74-83.

MASON-BROWN, J. J. (1948), Brit. F. Surg. War Surgery Suppl. No. 2, 354 .

MATAS, R. (1903), Ann. Surg., 37, 161.

MAYBURY, B. C (1952), personal communication.

MED. RESEARCH COUNCIL (1944), War Memorandum No. $13:$ MILLER, H. H., and WELCH, C. S. (1949) Ann. Surg., 130, 428-438.

MURPHY, J. B. (1897), Med. Record, 51, 73-88.

MURRAY, G., and JANES, J. M. (1940), Brit. med. F., ii, 6-7.

MUSTARD, W. T. (1946), Ann. Surg., 124, 46. REBOUL, H., and LAUBRY, P. (1950), Proc. Roy. Soc. Med. ֶָ.

ROB, C. G. (1953), Ibid., 46, 123.

SHUMACKER, H. B., JUn., ABRAMSON, D. I., and LAMPERT, H. H. (1947), Surgery, 22, 950.

TUFFIER, T. (1915), Bull. Acad. de Med. Paris, 74, 455.

\title{
ADRENAL AMYLOIDOSIS AS A CAUSE OF ADDISON'S DISEASE
}

\author{
By S. CoPE, M.D., M.R.C.P. \\ Senior Medical Registrar, David Lewis Northern Hospital, Liverpool \\ and J. C. WoonRow, M.B., M.R.C.P. \\ Senior House Officer, Broadgreen Hospital, Liverpool
}

The first mention of the relationship of adrenal amyloidosis to Addison's disease was by Riesman (1898). Examination of his paper reveals that the patient described was not suffering from Addison's disease, though there was amyloid infiltration of the adrenal glands. A close search shows that a number of the subsequently described cases were based on inadequate evidence. We believe the first acceptable case should be attributed to Schlesinger in 1917 .

The most recent review on the subject was that of O'Donnell in $195^{\circ}$ in a paper in which he discusses the changing pathogenesis of Addison's disease. Subsequent to this paper Heller and Camarata (1950) have published a further case.

A patient suffering from generalized amyloidosis and showing definite evidence of Addison's disease was recently under our care.

This patient, a man aged sixty-five, was originally referred to a hospital out-patients' department in May 195 $\mathrm{I}$; suffering from cough and loss of weight following an exacerbation of his chronic bronchitis. At that time he appeared quite ill, and was noted to have a generalized pigmentation, a blood pressure of $110 / 70$ and considerable albuminuria. Apart from the signs of generalized bronchitis, a comment was made that moist sounds 3 were particularly to be heard at the right apex.:An X-ray of the chest showed patchy shadowing at the extreme apices, but, despite careful search, no confirmatory evidence of tuberculosis was obtained. A barium meal and follow-througho showed no abnormality. Some improvement occurred and the patient was discharged.

We first saw him on March II, 1952, when he reported that for about three months he hadô suffered an exacerbation of his cough with then production of considerable quantities of muco-N purulent sputum, this following on an upper respiratory infection. He had also noticed swelling of his ankles and feet, frequency of micturition and progressive breathlessness on exertion. There冓 had been a marked feeling of weakness and considerable loss of weight, whilst just prior too 
admission he had developed right-sided pleural pain.

On examination his weight was $125 \mathrm{lb}$. and his general condition was poor. There was a moderately severe diffuse brown pigmentation on the face and trunk with lesser involvement of the limbs. The mucous membranes were not involved. The chest showed signs of emphysema and bronchitis and there was slight clubbing of the fingers.

There was oedema over the ankles and sacral regions, but no jugular congestion. His blood pressure was $100 / 70$ and the heart itself appeared clinically normal.

The liver showed moderate smooth enlargement, and the spleen was not palpable. The remainder of the examination did not reveal any abnormality.

The urine contained large amounts of albumin, a feature persisting throughout the illness, Esbach figures reaching as high as $12 \mathrm{~g}$. per litre. The specific gravity of the urine was 1,006 , and this varied during the illness from 1,006 to 1,014 on daily examination. Microscopic examinations revealed a varying number of hyaline casts and some granular casts. No red blood cells were seen. The blood urea was $38 \mathrm{mg} . \%$. The total serum protein was $4.9 \mathrm{~g} . \%$, albumin $3.4 \mathrm{~g} . \%$ and globulin $1.5 \mathrm{~g} . \%$.

An X-ray of the chest showed a good deal of shadowing in the middle and lower zones of both lungs, thought to be mainly fibrotic in origin, although there was also, undoubtedly, some pulmonary congestion.

The clinical picture, apart from the chronic chest condition, was that of a nephrotic syndrome. In addition we believed there to be coincidental Addison's disease. The question of amyloidosis was raised at this stage, but in view of his poor general condition no confirmatory evidence of this was sought.

However, it was considered justifiable to endeavour to establish the diagnosis of Addison's disease. A serum sodium was done-295 $\mathrm{mg} . \%$ and the serum potassium was $21.8 \mathrm{mg} . \%$. The Keppler factor was 12, but is unreliable in view of the impairment of renal function. An E.C.G. showed low-voltage QRS complexes with upright $\mathrm{T}$ waves only. ACTH tests for adrenal function were not attempted.

The oedema slowly increased and the blood pressure fell to $95 / 60$, remaining at this low level throughout the subsequent course of his illness.

In June he had a rather severe bout of diarrhoea lasting a few days. By this time the oedema had extended well up the abdominal wall. The serum albumin was $2.9 \mathrm{~g} \%$, and the serum globulin 2.2 g. \%. He showed an anaemia of 3.3 million RBCs with an haemoglobin of $62 \%$. The serum cholesterol was $300 \mathrm{mg} . \%$.

No form of treatment produced a significant improvement in his condition and at his own request he was permitted to go home.

He was re-admitted on August 2I with an exacerbation of all his symptoms, having in par- $\overline{\bar{c}}$ ticular lost a considerable amount of weight, and $\Phi$ had become a good deal paler. He had, in addition, developed a pain in the right iliac fossa ${ }^{\infty}$ where a mass could be palpated which was thought $\vec{\circ}$ to be a carcinoma of the caecum. His general $\overrightarrow{\vec{\omega}}$

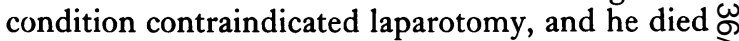
a week after admission.

\section{Post-mortem}

At autopsy the relevant findings were as follows :

In the chest there was a right-sided pleural effusion with dense adhesions elsewhere, the lungsing showing chronic bronchitis and emphysema with a small chronic abscess at the right apex. Section음 of the lung showed this chronic abscess to havea partly ulcerated epithelium replaced by vascular $Z$ granulation tissue. The surrounding parenchyma showed fibrosis. No evidence of active tuber-3 culosis could be found.

The right ventricle of the heart was dilated and hypertrophied.

There was an ulcerative thickening of the caectin which proved to be an Argentaffin cell carcinoma. Above this the gut was ballooned and congested and a recent peritonitis had occurred.

The liver and spleen showed diffuse amyloid infiltration.

The kidneys were extensively damaged by흘 amyloid, there being a loss of many glomeruli, and involvement of nearly all of them with their afferent arterioles.

The adrenal glands were enlarged and firm. 흘 There were dense masses of amyloid present:along the columns of the zona fasciculata, leading 3 . to great destruction of the cells. The deposits also involved the zona reticulosa to a great extent,, 3 leaving only a few areas relatively free from ${ }_{\circ}$ amyloid. The zona glomerulosa was less densely infiltrated than either the zona fasciculata or the zona reticulosa, but in places even this zone was almost completely replaced. There were dense $N$ masses of amyloid present in the walls of the $N$ veins (Figs. I and 2).

\section{Discussion}

As has been noted, we made a clinical diagnosis? of Addison's disease in life. This was based on the weakness, pigmentation and low blood pressure. The chemical tests, though at a superficialo- 


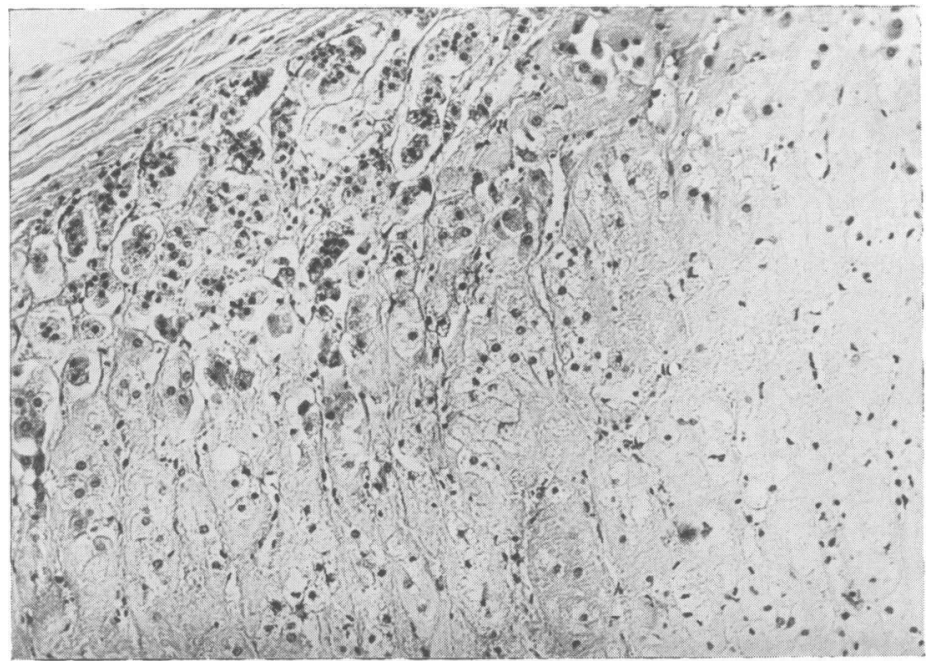

FIG. I.-Section through typical area of adrenal cortex; amyloid infiltration throughout, except for narrow rim of surviving cells in zona glomerulosa (H. \& E. $\times$ I 30).

glance confirmatory, are unreliable in the presence of a renal lesion. The destruction of the adrenals by amyloid in our case may be regarded as confirmatory evidence.

It is of interest to consider in more detail some of the previously described cases. Bronfin and Guttman (1935), in an excellent review, attempted to correlate the clinical and pathological features of this disease. They described five cases as definite examples, but of these five there was one case showing no pigmentation and with a blood pressure of I0o/80, whilst a second case had a blood pressure of $120 / 90$. In view of the presence of advanced tuberculosis as an alternative explanation for their symptoms, we feel that they cannot be accepted. The remaining three cases we would regard as fulfilling the necessary criteria.

We feel that one of O'Donnell's three cases is somewhat doubtful in that pigmentation was minimal and the blood pressure was 108/74.

In all, I 4 cases have been published which have had Addison's disease as a result of adrenal amyloidosis. Unfortunately, although Coltin (I935) described two undoubted cases, they are so sparse of detail as to be impossible of analysis. The remaining authors who have published cases, other than those already mentioned, are listed at the end of this article.

The ages of the patients varied from 22 to 53 years-the usual age group for Addison's disease. Our patient was, therefore, a good deal older than those previously described. There appears to be no significant difference in sex incidence (fi $\overline{e^{\circ}}$ women and seven men).

The cases were all diagnosed on the presence $\frac{0}{4} \overrightarrow{0}$ the typical features of Addison's disease; that pigmentation, low blood pressure and asthen No other criteria for the diagnosis could be accepted, as chemical tests for its proof were not done in any case, with the exception of the one described by Levenson et al., and here the ionic $\frac{}{\propto}$ patterns were complicated by extensive burns.

In O'Donnell's case 3 , the picture was due to음 primary amyloidosis and, in Levenson's most interesting description, the amyloid followed upon widespread burns. In McCutcheon's patient an hypernephroma was found, and Philpott attributed $\frac{3}{3}$ his case to syphilis. All other cases have beenassociated with advanced and widespread tuber- 3 . culosis. The association with tuberculosis appears to be the striking aetiological feature, but the point we wish to make here is that, in contra-o distinction to the more usual cases of Addison's? disease, widespread tuberculosis is the rule.

In our patient two possible causes for amyloid were present: (I) chronic lung abscess and (2) $N$ the slow-growing carcinoma. Although the abscess $N$ was small, it appears to us to be the more probable N explanation.

In all cases there was generalized amyloidosis, which should be easy of diagnosis by the usual methods. We would like to make particulare mention of the kidneys, since they are invariably involved, hence the usual chemical tests for 


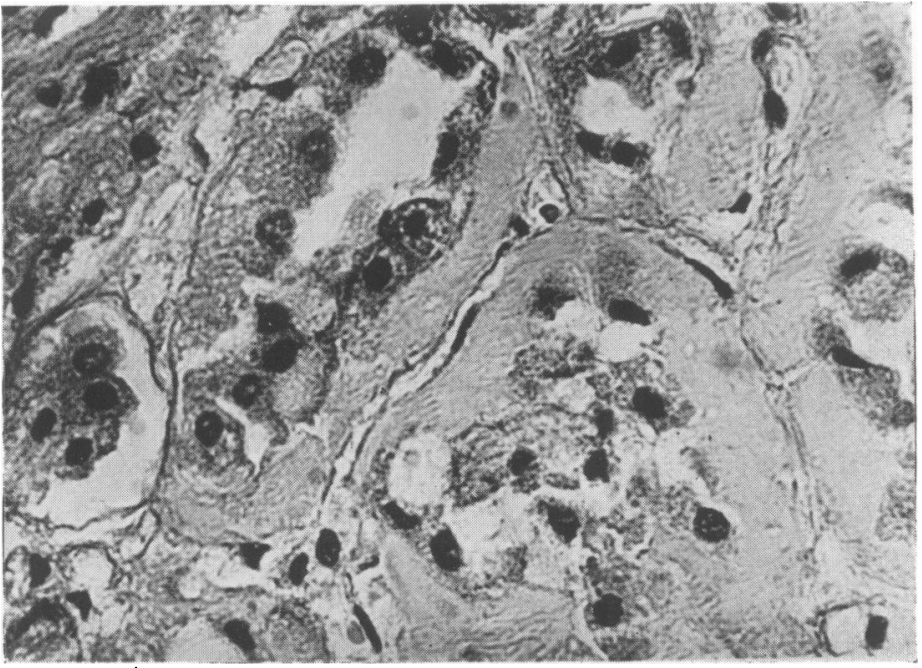

FIG. 2.-Amyloid change in peri-acinar connective tissues of zona glomerulosa (H. \& E. $\times$ 450).

Addison's disease cannot be employed. On the other hand, albumin is always to be found in the urine, and casts were present when they were sought. In many cases oedema was a feature of the clinical picture.

As has been noted in previous articles, histological examination shows widespread infiltration of the cortex by amyloid with much destruction of the cortical cells. The zona fasciculata and the zona reticulosa are invariably involved to an extensive degree, whilst the zona glomerulosa tends to be less affected.

\section{Conclusion}

It is evident that amyloid as a cause of Addison's disease is rare and difficult to diagnose. We would, however, echo previous authors in stating that we would suspect it of being more common in sanatoria than publications lead one to believe. We think it should be seriously considered in any case showing the features of Addison's disease with a nephrotic picture in which there appears to be an adequate primary cause for amyloidosis. This may become of significance in view of the iact that tuberculosis is now coming under greater therapeutic control, and it may be possible to halt or reverse the amyloid process.

\section{Summary}

A case of Addison's disease due to adrenal amyloidosis is presented.
A critical review of the literature is given.

An attempt has been made to point to the features which may indicate the complete diagnosis $\overrightarrow{0}$ during life.

We would like to thank Dr. C. A. Clarke for permission to publish this case, and Dr. F. Whitwell for the pathological details.

\section{BIBLIOGRAPHY}

BAUER, J. (1922), Klin. Wchnscher., 1, 1595.

BITTORF, A. (1910), Deutsches Arch. f. Klin. Med., 100, 116. BRONFIN, I. D., and GUTTMAN, P. H. (1935), Am. Rev.

Tuberc., 31, I.

COLTIN, W. A. (1935), M. Bull. Vet. Admin., 12, 27.

GUTTMAN, P. H. (1930), Arch. of Pathology, 10, 742, 895.

HELLER, E. L., and CAMARATA, S. J. (1950), Ibid., 49, 60I.

HUNTER, W. C., and RUSH, H. P. (1926), Ann. Clin. Med., 5, 404 .

LEVENSON, S. M., TAGNON, H. J., GOODPASTOR, W. I., GREEN, R. W. TAYLOR, F. H. L., and LUND, C. C. (1947), New England f. Medicine, 237, 152.

McCUTCHEON, M. (1923), Am. 7. Med. Sc., 166, 197.

MENDAL, D. L., and SAIBIL, M. (1938), Canad. M.A. F., 39, 457. O'DONNELL, W. M. (1950), Arch. of Int. Med., 86, 266.

PHILPOTT, N. W. (1928), Ann. Int. Med., 1, 613.

RIESMAN, D. (1898), Trans. Path. Soc. Phila., xvili, 428. SCHLESINGER, H. (1917), Wein Klin. Wchnscher., 30, 99. SCHULTZ, O. T. (1912), Cleveland M. Ұ., 11, 4. 